\title{
Accounting to the Workforce
}

\author{
Judy Brown*
}

In New Zealand the disclosure of accounting information to employees andlor trade unions is comparatively rare and is not required by law or encouraged by Government. Although there has been little debate, there is evidence of developing interest. This paper examines the rationales for and objections to labour-oriented disclosures.

\section{Introduction}

In recent years there have been signs of developing interest in New Zealand in the disclosure of accounting information to employees and unions. A number of companies have continued the practice, initiated during the 1970 s, of providing specialised annual reports to employees (Smith, 1985). Several workplaces are now covered by joint union/management consultative agreements and most of these contain information sharing clauses. Submissions to the Committee of Inquiry into Industrial Democracy by the Employers' Federation, (NZEF, 1989) Business Roundtable (NZBR, 1989) and Council of Trade Unions (NZCTU, 1989) all contained specific references to the concept of information disclosure. Further interest is also likely to be stimulated by current moves towards enterprise bargaining.

\section{Rationales for greater disclosure}

People of various political persuasions and both employers and unions have supported the idea of 'accounting to the workforce'. However, they frequently do so for very different reasons. The differences become apparent when comparisons are made of management and employee perspectives on disclosure.

\section{Management-espoused rationales}

Management-espoused rationales tend to reflect a unitary frame of reference, which is based upon a notion of fully shared interests. The enterprise is viewed as a functionally integrated and inherently harmonious system, analogous to a team. Managers, as the 'team captains', guide the organisation towards the attainment of profitability and efficiency goals which serve the rational purpose of all. This belief in common objectives and 'positive sum' relationships leads to a denial of organisational conflict, with adversarial attitudes being attributed to misunderstanding, stupidity or the work of 'agitators' (Fox, 1973).

Within this perspective, communication is viewed as a means of encouraging more responsible, co-operative and productive industrial attitudes. The expectation is that the 
provision of certain financial information will promote understanding of and identification with the disclosing company and thereby have a favourable impact on enterprise productivity and efficiency. Industrial relations may thus be conducted in a more 'rational and harmonious' way. The emphasis is strongly utilitarian, with no explicit recognition that employees or their representatives have rights to information. The strong preference is for disclosure to be left on a purely voluntary basis i.e. a matter of managerial prerogative.

Management initiatives in this area are not new. In the United Kingdom and the United States, the practice of 'employee reporting' has been traced back to the late nineteenth century and early twentieth century. Most of this early development was in relation to the operation of profit-sharing and co-partnership schemes and the emergence of trade unions (Hussey, 1981; Bougen, 1988). Authors from the 1920s, for example, promoted the use of staff house journals as a way of offsetting "the lost healthy intimacy of 'shirt sleeve' days of workman and boss" and as "a panacea to sweep away disloyalty, unrest, inefficiency and strikes" (Lewis, Parker and Sutcliffe 1984: 230).

During World War 2 there was a further surge of interest in connection with the establishment of workplace consultative committees to advise on productivity and efficiency. Around this time, attention was also being paid to the theories of the 'human relations' school of social psychology, which had its origins in the work of Mayo (1933). Human relations theorists placed great store upon 'employee communication schemes', claiming they would lead to greater harmony in the workplace and tangible rewards in company performance.

Burchell, Clubb and Hopwood (1981: 96-97) report that readers of United Kingdom management journals during the 1940 s and early 1950 s were greeted by headlines such as "Telling workers the facts"; "Scottish firm tells the workers "What and Why'" and "Workers had all the facts - up went efficiency". In the United States, employers were advised that employee reports could reach "to the very heart of some of the most serious labour problems" (Barloon, 1941: 124) and lead to "fewer strikes and other evidences of dislocations in the relations between management and employees" (Powlison, 1947: 145).

During the 1970s employer organisations in the United Kingdom, Australia and New Zealand actively promoted financial disclosures to employees as a central component of 'economic education' and 'employee involvement' programmes (Confederation of British Industry 1975, 1976, 1977; Enterprise Australia, 1978; NZ Chambers of Commerce 1977, 1980; NZEF 1980). The NZ Chambers of Commerce (1980) described its work in this area as part of an overall programme "designed to improve public understanding of business and to promote support for the competitive market concept". The NZEF (1980:18) emphasised the link between financial information and company identification, claiming that it "encourages employees to feel they belong, particularly if the company is successful and expanding".

Employers were warned that if they were not prepared to take the initiative in the area of employee communication "they may eventually be confronted with externally imposed statutory provisions which could seriously hinder the development and viability of private enterprise" (Confederation of Australian Industry, cited in Craig and Hussey 1982: 7).

In the event, voluntary disclosure initiatives did not prove completely successful in staving off the 'threat' of legislation. While the provision of financial information direct to employees remains a largely voluntary practice, labour representatives in the United States and United Kingdom have been granted rights of access to information for collective bargaining purposes. More recently, United Kingdom employers have also come under the influence of the European Community Disclosure Directives. Unions in New Zealand and Australia, however, have had little success in this area to date. 
When the issue of disclosure resurfaced recently in New Zealand in the context of the Labour Government sponsored inquiry into Industrial Democracy, the NZEF (1989: 2) again stressed the importance of communication in introducing "more effective co-operation and consultation" with the object of improving "efficiency, productivity, profits and the quality of life for everyone". In particular, the principles of "good communication and a sharing of information" were seen as having an important role to play in creating "mutual trust" between managements and employees. The Federation preferred not to involve unions in any such communications exercise on the grounds that their interests "would generally require that they advocate the disbursement of profits into wages or conditions or other forms of expenditure rather than into capital formation" (NZEF, 1989: 17).

\section{Employee-espoused rationales}

Whereas employer rationales concentrate on the prospects for unity and increased productivity, labour-oriented arguments tend to emphasise the social and moral responsibilities of management. Disclosure is not viewed simply as a route to increased productivity and efficiency. Employees are seen as having a right to be informed and consulted about the state and prospects of the organisations in which they work, regardless of the possible economic benefits to the organisation. Mandatory disclosure is supported on the grounds that, in order to be effective, the "moral right ... almost certainly needs converting into a legal right" (Owen and Harte, 1984: 184).

Employee-espoused rationales are based on a pluralistic world-view. Firms are viewed as coalitions of participants with diverse and at times conflicting interests and aspirations. Labour-management relationships encompass mixed motives; parties are simultaneously confronted with incentives to co-operate and incentives to compete. This makes the whole question of managerial governance problematic; the 'captains' of industry cannot necessarily be relied upon to look after the interests of all organisational participants. Conflict is based on genuinely different interests. It is inevitable but may be managed. The end result reflects some kind of 'negotiated order'.

Pluralists agree that concepts of information-sharing are fundamental to a more truly co-operative approach in the workplace and that the impact on productivity can be positive. However, information cannot eliminate the gaps between the priorities of management and those of the workforce. The real value of accounting information lies in its potential for managing the conflicts of interest that inevitably arise between capital and labour. Within such a framework, disclosure may, for example, be used to strengthen management accountability and to support industrial democracy and collective bargaining initiatives.

\section{(a) accountability}

The practice of preparing audited financial statements developed in an attempt to secure the accountability of managers to the providers of equity capital (Littleton, 1958). Indeed, accountability has been described as the 'backbone' of accounting (Ijiri, 1975). More recently there have been calls for recognition that employees have interests in the functioning of organisations at least as important as those of shareholders. Maunders (1981: 2), for example, observes that "both groups are dependent upon the organisation for earnings and both may be considered to have "capital' tied up in the organisation". 
Accountability is even more important given that employees, unlike shareholders, have little opportunity to diversify the risks associated with their investment relationship:

\begin{abstract}
Employees not only derive their income from enterprises which employ them, but they devote a large proportion of their daily lives to the enterprise. Decisions taken by or in the enterprise can have a substantial effect on their economic circumstances, both immediately and in the longer term; the satisfaction which they derive from work; their health and physicai condition; the time and energy which they can devote to their families and to activities other than work; and even their sense of dignity and autonomy as human beings (Moore, 1979: 42-43).
\end{abstract}

It has been suggested that employee interests could be served through the inclusion of more substantive labour-related information in corporate reports, for example, information on such matters as the range of incomes, superannuation contributions, maintenance of employee purchasing power, transfer pricing policies, levels and locations of employment, equal employment opportunities, skills training, health and safety records, and so on. Such disclosures, by providing greater visibility to particular issues, may influence management behaviour. Medawar (1978: 473) observes:

Power corrupts less when accounted for - because if decision-makers know they may be called upon to explain and justify the use of their powers, they are far more likely to make more considered and equitable decisions than they otherwise might.

The Accounting Standard Steering Committee (1975) makes a similar observation.

\title{
(b) Support of industrial democracy initiatives
}

Recognition of the extent to which employees are affected by decisions made in organisations has led not only to calls for more accountability but also for more worker participation in those decisions. Access to information is seen as a necessary prerequisite to informed and constructive participation, as "no realistic input can occur in the absence of knowledge" (NZCTU, 1989: 17).

Whereas accountability concerns may be satisfied through the external reporting function, effective worker participation inevitably requires access to internal management accounting data. If there is to be a genuine sharing of decision-making, employees need sufficient information to enable them to make their own, independent assessments. Information must be provided in a relatively 'raw' state and on a timely basis to allow for both the evaluation of management proposals and, where necessary, the development of alternative plans. Published "glossy" annual reports cannot hope to serve as an adequate proxy.

Indeed it seems probable that management information systems would currently be ill-prepared to service the requirements of industrial democracy schemes. Management poses questions and makes decisions within a particular framework and information is gathered and processed accordingly. Labour representatives are likely to take account of broader considerations. In the case of investment strategies, for instance, wage, job security and health and safety implications are likely to be accorded a higher priority by unions than management. Unions may have to look at negotiating the types of information collected or, perhaps, establish information systems of their own. 


\section{(c) Collective bargaining}

It has been claimed that information sharing is essential to the proper conduct of collective bargaining. The issue is largely one of procedural justice. Union leaders in Canada, for example, have complained that in most bargaining situations "They don't know what the real financial status of the employer is, nor do they know which (if any) of the conflicting figures published on profits and productivity are accurate" (Jain, 1981: 749). A United Kingdom Commission on Industrial Relations (1972: 21) stated:

Collective bargaining cannot take place at all without some information as a basis for the exchanges between the parties so there is no question that information is a necessary element in the whole process. The question at issue is not whether information in itself should play a role but whether each side should rely on its own resources. Employers often have access to more information than unions.

Access to accounting information in New Zealand is likely to become increasingly important in view of current trends towards enterprise and productivity bargaining. If this takes place in the absence of systematic disclosure the workforce may be inclined "to believe that they have got the worst of the deal" (Corinna and Reeves, 1981: 24).

Foley and Maunders $(1977,1984)$ suggest that, in discussing collective bargaining issues, the distinction between integrative 'win-win' environments and distributive 'win-lose' environments is useful. In integrative bargaining a 'problem-solving' approach can be taken. The more relevant information the parties share, the better the problem-solving approach is likely to function, for example through more adequate problem definition, generation of more ideas and improved evaluation of those ideas.

In distributive bargaining decision-making is more political. Information becomes a power resource for use in what is an essentially competitive situation. It may be used to "confuse, mystify or convince" (Cooper, 1984: 128) in an attempt to influence the outcome in one's own favour. For example, warnings by a company of low profitability may alter union perceptions of the consequences of pressing a pay demand. Management may or may not be trying to revise union perceptions in the direction of 'truth' (although opportunities for opportunistic behaviour are limited by the requirement that information be credible to the union).

Foley and Maunders suggest that these differing bargaining contexts go some way to explaining why managements may be reluctant to 'open the books'. More liberal disclosure policies may benefit management in integrative bargaining situations. But they may lose a tactical weapon in distributive bargaining situations. The difficulty is that integrative processes almost always involve a distributive phase (Walton \& McKersie, 1965).

Foley and Maunders also discuss the potential for disclosure to act as an 'attitudinal structuring' tool, facilitating shifts towards more co-operative relationships and thereby increasing the possibility of 'good integrative payoffs'. They conclude that no generalisation can be made about the likely impact of disclosure on bargaining outcomes. Management's policy choice is likened to an investment decision with positive or negative cash flows in the short-term from distributive bargaining (depending on the content of information in relation to prior expectations) and possible positive cash flows in the longer-term (via the effects on integrative bargaining and attitudinal structuring). The more important issue, perhaps, is whether disclosure is properly a matter of management policy or a question of public policy. 


\section{Objections to increased disclosure}

There has been resistance to the idea of increased disclosure of accounting matters from both employers and unions. Again, the bases of their respective concerns are quite different.

\section{Employers' resistance}

Employer objections are fairly predictable and surface most often in the context of calls for mandatory disclosure. They centre around four main themes: the concept of managerial prerogative, the inability of employees and/or unions to understand information, the danger that labour recipients will 'misinterpret' information and confidentiality constraints.

\section{(a) The concept of managerial prerogative}

Company managements in general refuse to concede the principle of accountability to labour or the need for 'democratic' influences in the workplace. They fear that increased disclosure of information will enhance employee power and lead to a loss of control in areas which should remain the exclusive prerogative of management.

The Trade Union Congress, prior to the enactment of disclosure provisions in the United Kingdom Employment Protection Act 1975, observed that "the control of information about a company's activities has been a basic aspect of the managerial prerogative that has proved extraordinarily difficult to break down" (TUC, 1974).

Justifications for the concept of managerial prerogative centre around three main themes: the rights attached to property ownership, company law which endorses an over-riding responsibility to shareholders and various 'economic efficiency' arguments:

Management as owners or agents of owners must have control over their capital assets. ('The right to do what one likes with one's own.') As labour owns no part of these assets, the way in which they shall be utilised is solely a matter for the owners and their representatives (Storey, 1983: 103).

It is difficult for boards of directors to have direct responsibilities to various different bodies. In any conflict of interest there must be one over-riding responsibility. Company law has identified this responsibility as being to the shareholders whose money is invested in the company (Knight, 1979: 25).

It is in everyone's interests: consumers, shareholders, the nation, and workers alike, that managers be left alone to manage as they see fit. Management's way is the more efficient (Storey, 1983: 104).

\section{(b) Inability of employees or unions to understand information}

Research studies have found that employees and union representatives lack expertise in financial accounting (Lyall, 1975; Mitchell, Sams and White, 1981; Craig and Hussey, 1981). This lack of sophistication is frequently used to defend non-disclosure. The problem does not seem insurmountable. The point has been made, for example, that concerns about financial literacy have not hindered statutory disclosure to shareholders (Corinna and Reeves, 
1981). Obviously a basic understanding of concepts would develop if accounting data became a matter for regular disclosure and negotiation. However, it is agreed that this is insufficient on its own. In its submissions to the Committee on Industrial Democracy, the Council of Trade Unions stressed the importance of access to education in preparing employees to play a more participative role in the workplace. The problem of technical proficiency might also be alleviated by giving unions the right to call in financial advisors to obtain, interpret and analyse information and/or perform labour audits. A major difficulty with this is that the capabilities of accountants in the area of labour consultancy are likely to be limited by their own lack of industrial relations training. Thus, in addition to the notion of promoting accounting expertise within the labour movement, some thought might also have to be given to the inclusion of industrial relations programmes in accounting education.

\section{(c) Misinterpretation of information}

Company managements also fear that a lack of technical competence will lead labour recipients to 'misinterpret' information (Dickens, 1980), although the point has been made that what management views as misinterpretation may simply be a refusal to draw the same conclusions. Reeves (1980: 3 ) observes that management's instinct is to see its "interpretation of the facts as the only one that right-thinking people could reach". However interpretation of facts may differ in good faith when people have different philosophies and different values. Each side may look equally 'irrational' to the other. The Council of Trade Unions emphasised "the right to present alternative viewpoints (to management's)" as a further base requirement of industrial democracy (NZCTU, 1989: 17).

This issue is particularly important with respect to the provision of financial information because, contrary to popular opinion, there are few 'facts' in accounting. Popular notions of 'truth' as correspondence with an 'objective reality' are difficult to apply to accounting statements. Many accounting concepts - e.g., profit, financial position, depreciation etc. - have no independent existence. They represent abstract ideas resulting from the accounting process itself rather than neutral 'facts' capable of being verified through observation. Accountants can record financial transactions in a variety of ways without necessarily stepping outside accepted accounting practice. Different methods will lead to different profit figures, asset values, rates of return etc. This flexibility means that figures can be deliberately adjusted to give a particular financial result. Education is important to ensure that employees and their representatives are not easy targets for the various forms of 'creative' accounting.

A growing number of accounting researchers and practitioners are also beginning to acknowledge the limitations of conventional accounting practice. Cooper and Sherer (1984), for example, draw attention to its narrow, private basis and 'pronounced shareholder orientation'. They observe that such a system cannot necessarily be relied upon to lead to resource allocation decisions that are 'optimal' or 'rational' for employees or society as a whole. Conceptions of 'profit' and 'efficiency' change if one moves from a capital to a labour perspective or from a private to a community perspective. Again, contrary to public opinion, it is possible to 'argue with the figures'. Faced with accounting-backed arguments for redundancies, plant closures, wage restraints, etc. it may be possible to develop alternative accountings that lead to quite different conclusions.

In this context, it is important to realise that the critical issues concerning what matters should be accounted for and how they should be accounted for are not technical; they are 
political (Cooper and Sherer, 1984).

The idea of accounting information as a neutral arbiter in industrial relations disputes becomes less tenable in this light. Accounting information is never neutral. It is not simply something that exists 'out there' to be collated by people without interests and aspirations. As Cooper (1984: 128) observes "Values are implicit in the decision to produce information on one issue rather than another, to measure benefits or costs from one perspective rather than an alternative." However disclosure could be used to supply "a corrective to any limitations in management's perspective" (Reeves, 1980:18) and to facilitate 'conversation' or 'dialogue' between the parties (Morgan, 1988). Within a pluralistic perspective, it might thus be seen to contribute to a more fairly negotiated order.

\section{(d) Confidentiality}

Objections are frequently backed by claims that disclosure would endanger the competitive position of the organisation. The NZBR, in its submissions to the Committee of Inquiry into Industrial Democracy, stressed the importance of confidentiality of information to protect incentives for innovation:

Compelling information-sharing for the sake of information-sharing is likely to impose significant costs in cases where it does not contribute significantly to - or indeed threatens - the effective functioning of the company (NZBR, 1989: 12).

Similarly United Kingdom employers, when faced with calls for increased disclosure, argued that the kinds of information disclosed to employees should be strictly limited by "(c)onstraints arising out of competitive requirements and confidentiality..." (Confederation of British Industry, 1975).

A number of writers contend that managements seeking to defend non-disclosure have placed undue emphasis on confidentiality constraints, and the 1972 United Kingdom Commission on Industrial Relations noted that, "We met cases where employers viewed with dismay the idea of giving to unions information which was, in fact, freely available in the company's annual report" (Commission on Industrial Relations, 1972: 93). Moore (1979) draws attention to evidence from European countries where management's fears about more participative practices have proved largely groundless and notes that unions often receive sensitive information in the context of their existing dealings with companies. He also points to the extent of knowledge already existing about competitors and the insignificance of union representatives as offenders with respect to insider trading as opposed to directors, major shareholders and senior employees.

\section{Unions' resistance}

Resistance to increased disclosure on the part of management is perhaps not surprising. More interestingly, there has also been some resistance to the idea from within the union movement. This so-called 'ostrich approach' towards information disclosure "is characterised by a lack of interest in company information, or cynicism about its value, or even strong hostility towards securing and discussing company information (Gospel, 1978: 20).

Unionists and labour commentators with reservations about the value of greater 
'information sharing' have expressed four major fears: that employees run the risk of being drawn into supporting managerial aims/rationality, that disclosure could lead to a form of pseudo-participation, scepticism about the credibility and impartiality of management's facts and figures and doubts about the accounting profession's commitment to 'truth and fairness'.

\section{(a) Risk of incorporation of workers into managerial aims/rationality}

Some unionists fear that in pursuing company information, unions will become socialised into endorsing managerial objectives and rationality, and that as a consequence capital interests will be the major beneficiaries of increased disclosure:

Fancy formulae for calculating bonuses or the 'sharing' of 'added value', combined with the selective doling out of misinformation, add to the possibility of confusion amongst workers, and to the danger that some shop stewards may find themselves cosily incorporated into management's ethos and 'mysteries' (Coates and Topham, 1974: 109).

In essence, there is wariness about becoming involved in a discourse overwhelmed by the 'assumptions of capitalism' and over which labour interests have traditionally had little influence. Alternative accountings are given little chance of gaining legitimacy.

\section{(b) Pseudo-participation}

A number of writers (Dickens, 1980; Moore, 1979) have emphasised the importance of viewing disclosure issues in the context of trade union functions. Dickens suggests that information is of little value in the absence of concessions to workplace democracy. She observes, for example, that there appears "to be little point in pushing for disclosure of prospective information if planning remains a management prerogative" (1980: 25). Increased disclosure may be a necessary condition for 'real' participation, but it is not a sufficient one. Cooper (1984: 128) goes further and warns that disclosure can lead to a form of 'pseudo' participation, which serves to strengthen management's position:

\footnotetext{
Instead of investing in an array of direct controls (e.g. supervision and incentive schemes) over labour, managers may prefer to use information to create a sense of responsibility and integrate labour into the organisation. This is the approach which is frequently implicit in management's suggestions for information disclosure; it leaves managers with the control over business policy and investment and offers labour the appearance of participation and a shared (but false) sense of responsibility.
}

Whilst disclosure itself does not guarantee employee influence over organisational decision-making, it may increase pressures for reform. Some unionists are adamant that any offers of information should be taken up "since appetite grows with the eating" (Coates and Topham, 1974: 110). According to this view, disclosure can activate objectives and lead to the identification of new industrial relations issues by changing perceptions of such matters as pay discrepancies, job security prospects, managerial efficiency, etc. 


\section{(c) Scepticism about management's facts and figures}

Some writers have observed that the flexibility inherent in current accounting practice and the received view of accounting as a technical, objective and neutral discipline promoting 'rational decision-making' are highly functional for managers. Knights and Collinson (1987), for example, comment on the fatalistic acceptance by workers of accounting information to justify redundancies and plant closures. They attribute this lack of resistance to perceptions of figures as objective and factual. Gospel (1978: 25) observes that where there are large differences in expert power between management and unions, "an increase in information disclosure may provide the more powerful with the means of exercising their expertise" and therefore increasing power differences in the workplace. Information may be 'pre-processed' to support particular alternatives. In this context, it is interesting to observe O'Leary's (1985: 90) suggestion that accountants owe a duty to those whose welfares are affected by accounting to make them more aware of the "inadequacies and areas of doubt" in accounting so they are "better able to defend themselves":

In a Swedish survey which looked at union influence on accounting practices, one respondent remarked that union representatives "exhibited a curious combination of confidence and mistrust in accounting" (Jonsson, 1988: 149). There was a basic conception of accounting being capable of producing a 'true' image but at the same time companies were suspected of manipulating the information for their own purposes. In this context there have been complaints in the United Kingdom about the lack of opportunity for unions to verify information e.g. no access to original documents (Dickens, 1980).

Other writers have observed that some options may never be considered because of the value judgements underpinning the structure and content of accounting information systems. As Arrow (1974: 49) observes "if it is decided to collect no information relating to a certain class of decisions, these decisions are non-agenda". Union trustees of pension funds in the United Kingdom, for example, have complained that they are unable to obtain financial information which does not rely on 'City' assumptions about what represents a good investment (Owen and Lloyd, 1985).

\section{(d) Doubts about the accounting profession's commitment to 'truth and fairness'}

There are also perceptions of the accountant as a tool of management. Difficulties relating to the perceived independence of auditors in the context of the management/shareholder relationship are well documented (Mautz and Hussein, 1961; Sherer and Kent, 1983; Montagna, 1986). And, as Foley and Maunders (1977) observe, this is probably a far more sympathetic relationship than the management/employee one.

The accounting profession has at times supported the idea of increased disclosure to labour. The Corporate Report, a widely-publicised United Kingdom discussion document on financial reporting, gave strong backing to the idea that employees have 'rights' to information:

Nothing illustrates more vividly the nineteenth century origin of British company law than the way in which employees are almost totally ignored in the present Companies Acts and in corporate reports. The 1967 Companies Act introduced a requirement for companies with more than 100 employees to state in the directors' report the average number of employees per week and the aggregate remuneration paid. This modest requirement barely does justice 
to the role of companies as the life support systems for millions of people (Accounting Standards Steering Committee, 1975: 51).

The relevance of an employee perspective for the development of accounting policy has also been acknowledged with the appointment of labour representatives on some overseas standard setting bodies.

However, it is probably fair to say that the views of the profession have more generally been closest to those of management. Disclosure has tended to be seen in terms of 'good' communications, with emphasis on the identity of interests between management and labour, the practical problems associated with 'mandatory' reporting and the need to preserve commercial confidentiality (Institute of Chartered Accountants in England and Wales, 1974; Consultative Committee of Accountancy Bodies 1975, 1976; Hundred Group 1976).

Jonsson (1988), in his survey of Swedish accounting policymaking, found that other members of the standard setting body had difficulty in understanding what union representatives meant. Union representatives were also seen as using a political basis for their argumentation. This hardly seems surprising if one accepts the point made earlier that differences in values and perspectives will lead to different conclusions about how things should be accounted for. And perhaps it is not until there is a clash of 'world views' that the inherently political nature of many accounting issues becomes apparent. Owen and Harte (1984) suggest that accountants are likely to be reluctant to support the concept of increased disclosure while company management generally refuses to concede the principle of employee accountability. This raises some fundamental questions for the profession about just whose interests accountants are or should be protecting.

Marques (1976: 178) posed the question: "Are people a resource for the enterprise or is the enterprise a resource for people?" Current accounting theory and practice would certainly appear to favour the former view. Accounting is based on a primarily proprietary model of the firm, with moves towards a 'self-entity' concept. The organisation is viewed as an instrument for maximising shareholders' wealth or, according to the self-entity theory, as existing for its own purposes. Either way, labour simply becomes a cost to be minimised. Disclosures are primarily oriented to the capital markets. Attention is focused on private efficiency rather than on social efficiency. However, as indicated earlier, there are signs of change. In this context, it seems appropriate that accountants and others be warned not to attribute to current accounting concepts and classifications "a facticity and an immutability to which they are not entitled" (O'Leary, 1985: 89).

The 'ostrich' approach to disclosure reflects a radical perspective in terms of Fox's (1973) framework. The radical view is essentially a critique of the pluralist perspective. Radicals claim that the pluralist view implies a degree of equality between stakeholder parties which simply does not exist. It assumes, for example, that grievances are recognised and acted upon and that decision-making arenas are open to any organised group. Radicals stress that agendas may be controlled and that potential issues may be kept out through the forces of socialisation so that anyone challenging the status quo will be labelled a 'trouble maker'. For radicals, capital can never be 'just another interest group'.

Disclosure, according to the radical view, is simply an exercise in indoctrination; a managerial strategy for obtaining co-operation and securing compliance from employees for managerial values and objectives (Ogden and Bougen, 1985). Management uses accounting information to implement its preferences by creating partial and one-sided views of reality and by shaping decision-making in accordance with capital-oriented values and perspectives. This 
lends a kind of selective visibility to the world which plays an important role in influencing what people see as problematic, possible, desirable and significant. Because labour interests cannot hope to enter the discourse on more or less equal terms, unions are well advised to eschew the world of accountancy and concentrate on more traditional methods of protecting employee interests.

\section{Conclusion}

Trade unions and employers have widely differing expectations of the need for and consequences of greater disclosure of accounting information. Managerial perspectives on disclosure tend to be unitarist in nature. Communication, when supported, is valued in terms of its potential for removing misunderstandings, encouraging a sense of responsibility in the workforce, eliminating 'us and them' attitudes, cultivating employee identification with the organisation and motivating employees on to the achievement of common goals. Accounting is thus considered to have the capacity to contribute to improved productivity and more rational and harmonious industrial relations. Suggestions of an enforceable 'right' to information are generally viewed as contrary to the 'proper purposes' of communication. Disclosure issues are considered to be rightfully a matter of managerial prerogative.

Employee-espoused rationales tend to reflect a pluralistic frame of reference. Disclosure, backed by legal prescription, provides a basis for managing the conflicts of interest that inevitably arise between capital and labour. It may be used, for example, to strengthen management accountability, to support industrial democracy initiatives and for collective bargaining purposes. Any notion of accounting information as an apolitical and neutral arbiter becomes less tenable in this light. People with different values and interests will want to 'account' for things differently. Alternative accountings consistent with labour interests and aspirations are required to facilitate 'dialogue' between the parties and thereby facilitate a more fairly negotiated order.

According to the radical perspective, disclosure can best be understood in terms of the hegemonic domination of capital. Information sharing is merely a managerial strategy for inducing co-operation and securing compliance from employees for managerial values and objectives. Management uses accounting information to lend a kind of selective visibility to the world. The result is the creation of partial and one-sided views of reality which reinforce the shaping of decision-making in accordance with capital-oriented perspectives. Radicals doubt the chances of 'alternative accountings' acquiring legitimacy and believe that, given present conditions, it is improbable that accounting could serve simultaneously the interests of employers and employees.

In drawing attention to these various perspectives, it is hoped that this paper will stimulate further discussion on the issues. The author also hopes that any preconceived notions readers may have had about accounting being a 'boring technical activity' devoid of political significance have been well and truly dispelled. Any remaining sceptics may wish to ponder the following extract from Tinker (1985: xv-xvi):

The systematic understatement of accounting's significance is reflected in the images of accountants in popular culture: as the technician, the innocuous bookkeeper, the 'ink-stained wretch,' the record-keeper whose lack of creativity makes him trustworthy. ....(Accountants may be seen) not as harmless bookkeepers, but as arbiters in social conflict, as architects of unequal exchanges, as instruments of alienation, and as accomplices in the expropriation of life experiences of others. 


\section{References}

Accounting Standards Steering Committee (1975), The Corporate Report, London, Institute of Chartered Accountants in England and Wales.

Arrow, K. (1974), The Limits of Organisation, Toronto, George McLeod.

Barloon, M.J. (1941), Financial Reporting to Employees, Harvard Business Review, 20(1): 124-31.

Bougen, P. (1988), Accounting and Industrial Relations, New York, Garland Publishing.

Burchell, S., Clubb, C. and Hopwood, A. (1981), A Message from Mars - and Other Reminiscences from the Past, Accountancy, 92(1058): 96-100.

Coates, K. and Topham, T. (1974), The New Unionism, Middlesex, Penguin.

Commission on Industrial Relations (1972), Disclosure of Information, London, HMSO.

Confederation of British Industry (1975), The Provision of Information to Employees, London, CBI.

Confederation of British Industry (1976), In-company Communication - an Analysis of the Immediate Tasks, London, CBI.

Confederation of British Industry (1977), Communication with People at Work, London, CBI.

Consultative Committee of Accountancy Bodies (1975), Memorandum on the Industry Bill, London, Institute of Chartered Accountants in England and Wales.

Consultative Committee of Accountancy Bodies (1976), Memorandum on Disclosure of Information to Trade Unions for Collective Bargaining, London, Institute of Chartered Accountants in England and Wales.

Cooper, D.J. (1984), Information for Labour, In B. Carsberg and T. Hope (eds.), Current Issues in Accounting, Oxford, Philip Allen.

Cooper, D.J. and Sherer, M.J. (1984), The Value of Corporate Accounting Reports: Arguments for a Political Economy of Accounting, Accounting, Organizations and Society, 9(3/4): 207-232.

Corinna, J. and Reeves, W. (1981), The Disclosure of Company Information to Trade Unions and Employees, University of Sydney Occasional Papers in Industrial Relations, No.2, June.

Craig, R. and Hussey, R. (1981), Employee Reports - What Employees Want, The Chartered Accountant in Australia, 51(10): 29-34. 
Craig, R. and Hussey, R. (1982), Keeping Employees Informed, Sydney, Butterworths.

Dickens, L. (1980), Disclosure of Information to Trade Unions in Britain, SSRC Industrial Relations Research Unit, University of Warwick, Coventry.

Enterprise Australia (1978), A Guide to Employee Annual Reports, Sydney.

Foley, B.J. and Maunders, K.T. (1977), Accounting Information Disclosure and Collective Bargaining, London, Macmillan.

Foley, B.J. and Maunders, K.T. (1984), Information Disclosure and the Role of the Accountant in Collective Bargaining - Some Comments, Accounting, Organizations and Society, 9(1): 99-106.

Fox, A. (1973), Industrial Relations: a Social Critique of Pluralist Ideology, In J. Child (ed.), Man and Organisation, London, George Allen and Unwin.

Gospel, H. (1978), The Disclosure of Information to Trade Unions: Approaches and Problems, Industrial Relations Journal, 9(3): 18-26.

Hundred Group (1976), Financial Information for Employees, London and District Society of Chartered Accountants.

Hussey, R. (1981), Developments in Employee Reporting, Managerial Finance, 7(2): 12-16.

Ijiri, Y. (1975), Theory of Accounting Measurement, American Accounting Association.

Institute of Chartered Accountants in England and Wales (1974), Accounting and Social Responsibility, London, ICAEW.

Jain, H. (1981), Disclosure of Corporate Information to Trade Unions in North America, Relations Industrielles, 36(4): 748-771.

Jonsson, S. (1988), Accounting Regulation and Elite Structures, John Wiley \& Sons.

Knight, Sir Arthur (1979), The Aims and Objectives of Corporate Bodies, In Institute of Chartered Secretaries and Administrators Corporate Governance and Accountability, London.

Knights, D. and Collinson, D. (1987), Disciplining the Shopfloor: a Comparison of the Disciplinary Effects of Managerial Psychology and Financial Accounting, Accounting, Organizations and Society, 12(5): 457-77.

Lewis, N., Parker, L.D. and Sutcliffe, P. (1984), Financial Reporting to Employees: Towards a Research Framework, Accounting and Business Research, 14(55): 229-239.

Littleton, A.C. (1958), Accounting Rediscovered, Accounting Review, 33: 246-53. 
Lyall, D. (1975), Opening the Books to the Workers, Accountancy, 86(978): 42-44.

Marques, E. (1976), Human Resource Accounting: Some Questions and Reflections, Accounting, Organizations and Society, 1(2/3): 175-78.

Maunders, K. (1981), Accounting Information and Industrial Relations: Towards a Managerial Evaluation of the Disclosure Policy Decision, Managerial Finance, 7(2): 2-5.

Mautz, R.K. and Hussein, A.S. (1961), The Philosophy of Auditing, American Accounting Association.

Mayo, E. (1933), The Human Problems of an Industrial Civilisation, New York, Macmillan.

Medawar, C. (1978), What is Accountability?, Accountant's Magazine, 82(869): 472-474.

Mitchell, F., Sams, K.I. and White, P.J. (1981), Financial Disclosure to Employees - a Managerial View, Accountant's Magazine, 85(898): 110-112 and 85(899): 152-154.

Montagna, P. (1986), Accounting Rationality and Financial Legitimation, Theory and Society, 15: $103-138$.

Moore, R. (1979), Disclosure of Company Information to Trade Unions, Oxford, Ruskin College.

Morgan, G. (1988), Accounting as Reality Construction: Towards a New Epistemology for Accounting Practice, Accounting, Organizations and Society, 13(5): 477-485.

NZ Business Roundtable (1989), Industrial Democracy: a Case for Regulation or Deregulation?, A Submission to the Committee of Inquiry into Industrial Democracy, Wellington.

NZ Chambers of Commerce $(1977,1980)$, How and Why to Report Business Results to Employees, Wellington.

NZ Council of Trade Unions (1989), Submission to the Industrial Democracy Committee of Inquiry, Wellington.

NZ Employers' Federation (1980), Managing Employee Involvement, Wellington.

NZ Employers' Federation (1989), Submissions to the Committee of Inquiry on Industrial Democracy, Wellington.

Ogden, S. and Bougen, P. (1985), A Radical Perspective on the Disclosure of Accounting Information to Trade Unions, Accounting, Organizations and Society, 10(2): 211-224.

O'Leary, T. (1985), Observations on Corporate Financial Reporting in the Name of Politics, Accounting, Organizations and Society, 10(1): 87-102. 
Owen, D.L. and Harte, G.F. (1984), Reporting on Corporate Accountability to the Workforce, Accountant's Magazine, 88(935): 184-187.

Owen, D. and Lloyd, A.J. (1985), The Use of Financial Information by Trade Union Negotiators in Plant Level Collective Bargaining, Accounting, Organizations and Society, 10(3): $329-50$.

Powlinson, K. (1947), Explaining the Facts to Employees, Harvard Business Review, 25(2): 145-57.

Reeves, T.K. (1980), Information Disclosure in Employee Relations, Employee Relations, 2(3): 1-39.

Sherer, M. and Kent, D. (1983), Auditing and Accountability, London, Pitman.

Smith, A. (1985), Employee Reporting in New Zealand, MCA thesis, Victoria University of Wellington.

Storey, J. (1983), Managerial Prerogative and the Question of Control, London, Routledge and Kegan Paul.

Tinker, T. (1985), Paper Prophets, New York, Praeger Publishers.

Trade Union Congress (1974), Industrial Democracy, London.

Walton, R.E. and McKersie, R.B. (1965), A Behavioural Theory of Labour Negotiations, New York, McGraw-Hill. 